\author{
MARIAN KOZACZKA \\ Uniwersytet Pedagogiczny w Krakowie, Polska \\ Pedagogical University of Krakow, Poland
}

\title{
Społeczna odpowiedzialność spółek zarządzających polskimi specjalnymi strefami ekonomicznymi
}

\section{Social Responsibility of Companies Managing Polish Special Economic Zones}

Streszczenie: W Polsce istnieje 14 specjalnych stref ekonomicznych, wydzielonych terenów, na których działalność gospodarcza jest prowadzona na preferencyjnych warunkach. Strefy podzielone są na podstrefy i rejony inwestycyjne, które mają pozyskiwać inwestorów krajowych i zagranicznych, wpływać na rynki pracy, wspierać eksport, pobudzać do aktywności lokalne społeczności, podmioty gospodarcze, instytucje. Polskie specjalne strefy ekonomiczne zarządzane są przez spółki z ograniczoną odpowiedzialnością lub spółki akcyjne, w których Skarb Państwa posiada większość głosów. Taki system zarządzania pozwala na zachowanie kontroli państwa nad strefami i kierunkami ich rozwoju oraz na szybkie wdrażanie na ich terenie projektów inwestycyjnych. Artykuł ma na celu określenie efektów finansowych spółek zarządzających polskimi specjalnymi strefami ekonomicznymi, ich wkładu w rozwój społecznej odpowiedzialności, uzyskanie odpowiedzi na pytania: czy istnieje relacja pomiędzy zyskami spółek zarządzających a poziomem ich społecznej odpowiedzialności, jakie inne czynniki wpływają na ich zaangażowanie w społeczną odpowiedzialność. W pracy zastosowano metodę analizy dokumentów. Jej wyniki potwierdzają wzrastający udział spółek zarządzających strefami ekonomicznymi w odbudowie i rozwoju szkolnictwa zawodowego, w organizowaniu i finansowaniu konkursów, festiwali, tworzeniu systemów stypendialnych dla uczniów szkół średnich, studentów. Największy wkład w kształtowanie społecznej odpowiedzialności miały spółki z dużymi kapitałami, wysokimi zyskami, zarządzające największymi strefami ekonomicznymi.

\begin{abstract}
In Poland, there are 14 special economic zones, separate areas, where economic activities are carried out on preferential terms. Zones are divided into sub-zones and investment areas, which are intended to attract domestic and foreign investors, influence labour markets, support exports, stimulate the activity of local communities, economic operators, institutions. Polish special economic zones are managed by limited liability companies or public limited companies, in which the State Treasury holds a majority of the votes. Such a management system allows to maintain state control over zones, directions of their development, rapid implementation of investment projects on their territory. The purpose of the article is to define the financial effects of companies managing Polish special economic zones, their contribution to the development of social responsibility, to answer the following questions: is there a relationship between the profits of management companies and the level of social responsibility, what other important factors affect their involvement in social responsibility.The work uses a method of document analysis, its results confirm the increasing participation of companies managing economic zones in the reconstruction and development of vocational education, in the organisation and financing of competitions, festivals, the creation of scholarship
\end{abstract}


systems for high school students, university students. Companies with large capital, high profits, managing the largest economic zones accounted for the largest share of social responsibility.

Słowa kluczowe: gospodarka; społeczna odpowiedzialność; spółka; strefa ekonomiczna

Keywords: company; economic zone; economy; social responsibility

Otrzymano: 24 lutego 2020

Received: 24 February 2020

Zaakceptowano: 31 maja 2020

Acceped: 31 May 2020

\section{Sugerowana cytacja / Suggested citation:}

Kozaczka, M. (2020). Społeczna odpowiedzialność spółek zarządzających polskimi specjalnymi strefami ekonomicznymi. Prace Komisji Geografii Przemysłu Polskiego Towarzystwa Geograficznego, 34(3), 207-219. doi: $10.24917 / 20801653.343 .14$

\section{WSTĘP}

Specjalne strefy ekonomiczne należą do licznej rodziny stref uprzywilejowanych, wydzielonych terenów, na których działalność gospodarcza jest prowadzona na preferencyjnych warunkach. Szybki rozwój stref uprzywilejowanych nastąpił na przełomie XX i XXI wieku, w okresie wzrastającej globalizacji i wzrostu przepływu bezpośrednich inwestycji zagranicznych. W 1997 roku na świecie było 845 stref uprzywilejowanych, a 10 lat później już ponad 3 tys. (Ernst \& Young, 2011: 28).

Dynamiczny rozwój stref uprzywilejowanych na przełomie XX i XXI wieku, w tym specjalnych stref ekonomicznych, parków technologicznych, naukowych, przemysłowych, doprowadził do wykształcenia w nich wielu nowych instrumentów, powstania dużego zróżnicowania w zakresie ulg i preferencji podatkowych, dania możliwości działania w nich zarówno firmom produkcyjnym, jak i usługowym, stworzenia przywilejów i zachęt w formie licznych pakietów inwestycyjnych i administracyjnych.

Wśród stref uprzywilejowanych naczelne miejsce zajmują specjalne strefy ekonomiczne, które mają pozyskiwać inwestorów krajowych i zagranicznych, wpływać na lokalne i regionalne rynki pracy, tworzyć nowe obszary przemysłowe. Ich zadaniem jest również zagospodarowanie majątku państwowego, wdrażanie w życie osiągnięć technicznych i technologicznych, wspieranie eksportu, pobudzanie do aktywności społeczności lokalnych i regionalnych, firm, instytucji.

W Polsce specjalne strefy ekonomiczne tworzone były na podstawie ustawy z 1994 roku (Ustawa z dnia 20 października 1994 r.) i na mocy decyzji Rady Ministrów. W latach 1995-1997 na mocy rozporządzeń Rady Ministrów utworzono w Polsce 17 specjalnych stref ekonomicznych, spośród których w dalszych latach dwie - Częstochowska Specjalna Strefa Ekonomiczna i Mazowiecka Specjalna Strefa Ekonomiczna Technopark Modlin - zostały rozwiązane z powodu braku zainteresowania inwestorów, a kolejne dwie - Specjalna Strefa Ekonomiczna „Tczew” i Specjalna Strefa Ekonomiczna „Żarnowiec” - zostały połączone w jedną strefę pod nazwą Pomorska Specjalna Strefa Ekonomiczna (Kozaczka, 2015: 27-34).

Od połowy 2001 roku w Polsce istnieje 14 specjalnych stref ekonomicznych o zróżnicowanym obszarze i różnej sile oddziaływania na regionalne kwestie społeczne oraz ekonomiczne. Co pewien czas ich obszary były powiększane o kolejne podstrefy i tereny inwestycyjne, na co znaczący wpływ mieli inwestorzy i władze samorządowe. Dla wielu gmin i powiatów utworzenie podstref oraz rejonów inwestycyjnych było panaceum na 
lokalne problemy społeczne i gospodarcze. Władze gmin i powiatów liczyły na to, że przyczynią się one do wzrostu zatrudnienia, wzrostu dochodów z podatków PIT i CIT, zmniejszenia wydatków na pomoc społeczną.

W 2007 roku na terenie Polski było 155, a pod koniec 2014 roku 358 podstref i rejonów inwestycyjnych (Kozaczka, 2015, s. 62, 108). Duża liczba podstref i rejonów inwestycyjnych była korzystna dla wielu podmiotów, zwłaszcza dla małych i średnich firm, które z reguły nie dysponują dużym kapitałem, a znajdowały się w ich pobliżu i mogły podjąć w nich działalność. Spora liczba podstref i rejonów inwestycyjnych dawała inwestorom duże możliwości w zakresie wyboru miejsc pod inwestycje, pojawienie się w podstrefie dużego inwestora gwarantowało napływ innych inwestorów, firm transportowych, instytucji z otoczenia biznesu. Władze państwowe, aby zachować kontrolę nad rozwojem terytorialnym stref, co pewien czas określały ich ogólny obszar. Na mocy ustawy z 2004 roku całkowity obszar wszystkich stref został podwyższony do 8 tys. ha (Ustawa z dnia 30 kwietnia 2004 r.), w 2006 roku do 12 tys. ha (Ustawa z dnia 23 czerwca 2006 r.), w 2008 r. do 20 tys. ha (Ustawa z dnia 30 maja 2008 r.), w 2015 roku do 25 tys. ha (Ustawa z dnia 22 stycznia 2015 r.).

W 2018 roku polskie specjalne strefy ekonomiczne obejmowały tereny położone w 186 miastach i w 308 gminach, o łącznej powierzchni 22 883,6 ha. Największe obszary zajmowały strefy: wałbrzyska, katowicka, kostrzyńsko-słubicka, łódzka, mielecka, pomorska, najmniejsze: słupska, suwalska, starachowicka, kamiennogórska.

Ogólne zatrudnienie w polskich strefach ekonomicznych w 2018 roku wynosiło 379070 osób i było wyższe o 7,4\% w porównaniu do roku poprzedniego. W 2018 roku w strefach przybyło 26 tys. miejsc pracy, w tym w strefie mieleckiej 4,7 tys., w katowickiej 4,4 tys. W tym roku w żadnej strefie ekonomicznej liczba zatrudnionych osób nie była niższa, aniżeli w 2017 roku (Ministerstwo Przedsiębiorczości i Technologii, 2019, s. 6-9, 15-16).

Od połowy 2018 roku preferencje i ulgi podatkowe obowiązują nie tylko w specjalnych strefach ekonomicznych. Ustawa o wspieraniu nowych inwestycji specjalną strefą ekonomiczną (Ustawa z dnia 10 maja 2018 r.) objęła cały kraj, a wydane na jej podstawie Rozporządzenie Rady Ministrów w sprawie pomocy publicznej udzielanej niektórym przedsiębiorcom na realizację nowych inwestycji (Rozporządzenie... z dnia 28 sierpnia 2018 r.), po spełnieniu określonych warunków, gwarantuje ulgi podatkowe przy tworzeniu nowych inwestycji każdej firmie, w każdym mieście, gminie, zwłaszcza w regionach o wysokim bezrobociu, w małych i średnich miastach tracących funkcje społeczne i gospodarcze.

W strefach ekonomicznych położonych w zachodniej części Polski dominuje kapitał zagraniczny, a na terenach wschodnich - kapitał polski. Grono największych firm działających w strefach ekonomicznych w 2018 roku stanowiły: Volkswagen Poznań sp. z o.o., Toyota Motor Manufacturing sp. z o.o., NGK Ceramics Polska sp. z o.o., Mondi Świecie S.A., Bridgestone Stargard sp. z o.o., Mondelez Polska Production sp. z o.o., Opel Manufacturing Poland sp. z o.o., Electrolux Poland sp. z o.o., Euroglas Polska sp. z o.o., UMA Investments sp. z o.o., LG Display Poland sp. z o.o., Mercedes-Benz Manufacturing sp. z o.o. W strukturze produkcyjnej stref ekonomicznych dominowały: pojazdy samochodowe, wyroby z gumy i tworzyw sztucznych, wyroby z papieru, wyroby chemiczne i elektroniczne (Ministerstwo Przedsiębiorczości i Technologii, 2019, s. 19). 


\section{SPÓŁKI ZARZĄDZAJĄCE POLSKIMI STREFAMI EKONOMICZNYMI}

Polskie specjalne strefy ekonomiczne zarządzane są przez spółki kapitałowe, spółki z o.o. albo spółki akcyjne, w których Skarb Państwa posiada większość głosów na walnym zgromadzeniu lub zgromadzeniu wspólników i jest uprawniony do powoływania i odwoływania większości członków zarządu i rady nadzorczej. Takie zarządzanie daje władzom państwowym pełną kontrolę i w razie potrzeby mogą poprawić działalność stref ekonomicznych.

Nazwy spółek zarządzających, z nielicznymi wyjątkami, są takie same jak zarządzane przez nie strefy ekonomiczne. Strefą katowicką zarządza Katowicka Specjalna Strefa Ekonomiczna S.A., kostrzyńsko-słubicką - Kostrzyńsko-Słubicka Specjalna Strefa Ekonomiczna S.A., krakowską - Krakowski Park Technologiczny sp. z o.o., legnicką Legnicka Specjalna Strefa Ekonomiczna S.A., łódzką - Łódzka Specjalna Strefa Ekonomiczna S.A., pomorską - Pomorska Specjalna Strefa Ekonomiczna sp. z o.o., słupską Pomorska Agencja Rozwoju Regionalnego S.A., kamiennogórską - Specjalna Strefa Ekonomiczna Małej Przedsiębiorczości S.A., starachowicką - Specjalna Strefa Ekonomiczna Starachowice S.A., suwalską - Suwalska Specjalna Strefa Ekonomiczna S.A., wałbrzyską - Wałbrzyska Specjalna Strefa Ekonomiczna Invest-Park sp. z o.o., warmińsko-mazurską - Warmińsko-Mazurska Specjalna Strefa Ekonomiczna S.A., mielecką i tarnobrzeską - Agencja Rozwoju Przemysłu Spółka Akcyjna (Ministerstwo Przedsiębiorczości i Technologii, 2019: 39).

Z wyjątkiem ARP S.A., w której Skarb Państwa posiada 100\% udziałów (Raport roczny..., 2017, s. 5-8), inne spółki zarządzające strefami nie otrzymują środków z budżetu państwa, działają na własnych dochodach. Ich dochody pochodzą z różnych źródeł, ze sprzedaży inwestorom gruntów i budynków położonych w strefach, z opłat za administrowanie i zarządzanie strefami, ze świadczonych usług, z dzierżaw. Spółki zarządzające strefami oferują liczne usługi, w tym usługi prawne, wynajem lokali i obiektów strefowych, sprzedaż mediów znajdujących się na ich terenie, inne świadczenia na rzecz inwestorów strefowych i innych podmiotów.

Przez wiele lat spółki zarządzające strefami zabiegały o powiększenie ich obszarów i pozyskanie jak największej liczby inwestorów, którym można było sprzedać lub wydzierżawić duże obszary stref. Od sprzedaży gruntów i budynków położonych w strefach w dużej mierze zależały dochody spółek zarządzających, ich sytuacja finansowa oraz aktywność inwestycyjna.

Dochody spółek zarządzających strefami pochodziły także z innych źródeł, były to środki z kredytów, pożyczek, odsetki od udzielonych pożyczek, odsetki z kont bankowych, zyski netto z działalności gospodarczej, w przypadku spółek akcyjnych również dochody z emisji akcji.

W ogólnych dochodach spółek zarządzających strefami ekonomicznymi spory udział mieli inwestorzy zagraniczni. Przeważnie zgłaszali oni duże zapotrzebowanie na tereny inwestycyjne, grunty, budynki, media strefowe. Do pozyskiwania inwestorów spółki zarządzające strefami, poza ogłoszeniami w środkach masowego przekazu, organizowaniem spotkań $i$ konferencji, wykorzystywały internet, który stał się ważnym źródłem informacji o firmach działających na ich terenie, warunkach inwestowania, ulgach podatkowych. Strony internetowe spółek zarządzających strefami ekonomicznymi zawierają informacje o wiodących inwestorach, organizowanych spotkaniach, konferencjach, ich uzupełnienie stanowią ilustracje budynków wiodących firm w strefach. 
W spółkach zarządzających strefami ekonomicznymi stałymi wydatkami pozostają wydatki osobowe na rzecz zarządu, rady nadzorczej, pracowników, wydatki na modernizację, rozbudowę i utrzymanie infrastruktury stref. Rozbudowa i modernizacja infrastruktury stref obejmuje sieć drogową, elektryczną, kanalizacyjną, wodociągową, budowę parkingów, chodników. Wydatki spółek zarządzających strefami, ponoszone na modernizację i rozbudowę infrastruktury gospodarczej i technicznej stref oraz z tytułu nabycia rzeczy służących do prowadzenia działalności gospodarczej na terenie stref, są odliczane od podatku dochodowego (Ustawa z dnia 20 października 1994 r.).

Spółki zarządzające strefami ekonomicznymi ponosiły również wydatki na promocję stref, spłatę kredytów, pożyczek, opłacenie podatków, ubezpieczeń, wspieranie instytucji. W trakcie negocjacji z inwestorami osiągnięcia spółek zarządzających strefami były niezwykle ważne, podobnie jak ich sytuacja finansowa, planowane nakłady na nowe inwestycje infrastrukturalne.

Spółki zarządzające strefami ekonomicznymi umożliwiają podmiotom gospodarczym prowadzenie działalności na terenie stref, gospodarują infrastrukturą stref, ich urządzeniami technicznymi i innymi składnikami mienia, prowadzą działania promujące podejmowanie działalności gospodarczej w strefach ekonomicznych i poza ich obszarem. Inne ważne zadania spółek zarządzających sprowadzają się do opieki nad inwestorami, pośrednictwa w ich kontaktach z władzami samorządowymi i rządowymi oraz właścicielami mediów, zbywaniu prawa wieczystego użytkowania gruntów objętych strefami na rzecz inwestorów, kontroli działalności inwestorów w strefach, a od września 2018 roku również do kontroli inwestorów, którzy otrzymali decyzje o wsparciu nowych inwestycji poza obszarem stref (Rozporządzenie Ministra Przedsiębiorczości i Technologii z dnia 29 sierpnia 2018 r.).

Spółki zarządzające mniejszymi strefami ekonomicznymi, położonymi w dalszej odległości od większych ośrodków miejskich, które nie pozyskały dużych inwestorów, z reguły notowały słabe wyniki finansowe. Skromne wyniki netto notowały także te spółki, które w danym roku dużo inwestowały, spłacały kredyty, pożyczki, nie zrealizowały na rzecz inwestorów dużych transakcji kupna-sprzedaży.

W latach 2017-2018 dobre wyniki finansowe notowały oddziały ARP S.A. zarządzające strefami mielecką i tarnobrzeską. W 2017 roku Oddział ARP S.A. w Mielcu, zarządzający strefą mielecką, uzyskał zysk netto w wysokości 4956 tys. zł, w następnym roku 10740 tys. zł. Oddział zarządzający strefą tarnobrzeską w tych latach uzyskał zysk netto w wysokości 18 220,4 tys. zł i 14 621,4 tys. zł. Z powierzonymi zadaniami dobrze radziły sobie Katowicka Specjalna Strefa Ekonomiczna S.A. i Kostrzyńsko-Słubicka Specjalna Strefa Ekonomiczna S.A. Zysk netto pierwszej spółki w 2017 roku wynosił 16 554,4 tys., a w 2018 roku 5359,7 tys. zł, zysk netto drugiej spółki wynosił 22 984,9 tys. zł, i 6560,7 tys. zł. Wałbrzyska Specjalna Strefa Ekonomiczna Invest-Park sp. z o.o. w 2017 roku uzyskała zysk netto w wysokości 11 852,8 tys. zł, w następnym roku 17 417,2 tys. zł. Łódzka Specjalna Strefa Ekonomiczna S.A. w 2017 roku osiągnęła zysk netto w wysokości 7402,8 tys. zł, a w następnym roku 7428,4 tys. zł.

Zyski netto innych spółek zarządzających strefami ekonomicznymi były zróżnicowane. Krakowski Park Technologiczny sp. z o.o. w 2017 roku uzyskał zysk netto w wysokości 1373,0 tys. zł, a w następnym roku tylko 707 tys. zł, Pomorska Specjalna Strefa Ekonomiczna sp. z o.o. w 2017 roku uzyskała zysk netto w wysokości 1479,1 tys. zł, a w następnym roku 1807,3 tys. zł. W tych latach Warmińsko-Mazurska Specjalna Strefa Ekonomiczna S.A. uzyskała zyski netto w wysokości 1647,4 tys. zł i 1251,1 tys. 
zł, zł, Specjalna Strefa Ekonomiczna Starachowice wygenerowała odpowiednio w 2017 i 2018 roku 613,0 tys. zł i 1509,9 tys. zł, zaś Specjalna Strefa Ekonomiczna Małej Przedsiębiorczości S.A. 555,1 tys. zł i 71,5 tys. zł. Ogólne zyski netto wszystkich spółek zarządzających strefami ekonomicznymi w 2017 roku wynosiły 98,7 mln zł, a w następnym roku $70,4 \mathrm{mln}$ zł.

Do 2019 roku spółki zarządzające strefami otrzymały wsparcie w postaci zwolnień podatkowych w wysokości $271,77 \mathrm{mln}$ zł. Do tego roku na promocje stref wydały $98 \mathrm{mln}$ zł, na budowę infrastruktury blisko 1,67 mld zł. W sumie na wymienione cele przeznaczyły blisko 1,77 mld zł, czyli kwotę ponad sześciokrotnie przewyższającą wysokość uzyskanych zwolnień podatkowych (Ministerstwo Przedsiębiorczości i Technologii, 2018: 39-43; 2019: 39-42).

\section{KIERUNKI AKTYWNOŚCI SPOŁECZNEJ}

Wśród licznych wydatków spółek zarządzających specjalnymi strefami ekonomicznymi znajdowały się środki przeznaczone na cele społeczne. Społeczna odpowiedzialność firm, spółek, instytucji oznacza uwzględnianie w ich działalności spraw społecznych, kwestii środowiskowych, utrzymywanie dobrych relacji z pracownikami, samorządami, organizacjami pozarządowymi. Społeczna odpowiedzialność organizacji to również odpowiedzialność za wpływ ich decyzji i działań na społeczeństwo i środowisko. Jest to koncepcja zarządzania zorientowana nie tylko na zysk i aspekty ekonomiczne, ale także na kwestie społeczne i ekologiczne (Jastrzębska, 2013, s. 37-42).

Działania w sferze społecznej odpowiedzialności posiadają charakter interdyscyplinarny. Firmy, aby zaznaczyć swoją obecność, wzbogacić wizerunek, coraz częściej sprawy społeczne włączają w strategie rozwojowe, decydują się na wspieranie lokalnych i regionalnych inicjatyw, pomagają w kształtowaniu środowiska naturalnego.

W społecznej odpowiedzialności stosowane są różne narzędzia, wynikające ze struktury organizacyjnej firm i kierunków ich działalności. Do powszechnie stosowanych narzędzi należały kampanie społeczne ukierunkowane na zmianę zachowań osób lub grup społecznych, programy które miały na celu integrację wokół wspólnych wartości, upowszechnianie wolontariatu, przekazywanie części zysków na cele społeczne.

Działania na rzecz społecznej odpowiedzialności są inwestycjami, które przynoszą korzyści firmom, gospodarce, społeczeństwu. Firmy uzyskują większe możliwości pozyskiwania nowych klientów i wzrostu sprzedaży produktów, ich misje stają się bardziej wiarygodne. Gospodarka zyskuje na wzroście cyrkulacji pieniądza, kształtowaniu innowacyjności i konkurencyjności, nawiązywaniu nowych kontaktów pomiędzy podmiotami i instytucjami. Społeczeństwo zyskuje na poprawie stanu środowiska naturalnego, kształtowaniu współpracy, postaw dobroczynnych, tworzeniu społeczeństwa obywatelskiego.

Do 2020 roku udział spółek zarządzających strefami ekonomicznymi w kształtowaniu społecznej odpowiedzialności był dynamiczny. Wspieranie różnych inicjatyw, promocja odnawialnych źródeł energii, organizowanie i współfinansowanie konkursów, festiwali, tworzenie systemów stypendialnych dla uczniów szkół średnich i studentów to niektóre kierunki ich działalności na polu społecznej odpowiedzialności.

Od kilku lat spółki zarządzające strefami ekonomicznymi aktywnie uczestniczą w odbudowie i rozwoju szkolnictwa zawodowego. Od reformy oświatowej w 1998 roku kształcenie zawodowe było coraz bardziej teoretyczne i powierzchowne. W latach 
1999-2015 liczba uczniów w szkołach zawodowych zmniejszyła się z 590,4 tys. do 178,8 tys. Na skutek emigracji zagranicznej i przejścia na emeryturę specjalistów różnych branż firmy miały coraz większe problemy kadrowe (GUS, 2019, s. 201; 2000: s. 223-226).

W 2016 roku Sejm przyjął ustawę prawo oświatowe, której istotną częścią było wprowadzenie nowej struktury szkolnictwa podstawowego i średniego. $\mathrm{Na}$ jej mocy utworzone zostały ośmioklasowe szkoły podstawowe, czteroletnie LO, pięcioletnie technika, trzyletnie branżowe szkoły zawodowe pierwszego stopnia i dwuletnie branżowe szkoły zawodowe drugiego stopnia, ponadto trzyletnie szkoły przysposobienia do zawodu, szkoły policealne dla osób z wykształceniem średnim o okresie kształcenia do 2,5 roku. Likwidacji uległy gimnazja. Podstawy kształcenia dla uczniów szkół podstawowych i średnich określa MEN, dostosowując kierunki i treści kształcenia do wymogów rynku pracy (Ustawa z dnia 14 grudnia 2016 r.; Ustawa z dnia 14 grudnia 2016 r. Przepisy wprowadzające...).

Spółki zarządzające strefami ekonomicznymi aktywnie włączyły się w akacje promujące szkolnictwo zawodowe, organizowały spotkania z dyrektorami szkół technicznych i zawodowych. Kostrzyńsko-Słubicka Specjalna Stefa Ekonomiczna S.A. zorganizowała kilka spotkań właścicieli firm z uczniami szkół zawodowych, uczestniczyła w tworzeniu nowych kierunków nauczania w szkołach zawodowych, w tworzeniu studiów dualnych w Wyższej Szkole Zawodowej w Kostrzynie nad Odrą, współtworzyła firmę symulacyjną Heban, prowadzącą kształcenie w warunkach zbliżonych do pracy w rzeczywistej firmie.

Łódzka Specjalna Strefa Ekonomiczna S.A. uczestniczyła w Forum Pracodawców, organizowała spotkaniach przedstawicieli firm strefowych z uczniami gimnazjów, dyrektorami szkół, doradcami zawodowymi, rodzicami. Spółka podpisała z władzami powiatu kutnowskiego i województwa łódzkiego porozumienie o otwarciu w Kutnie Centrum Kształcenia Ustawicznego Nowych Technologii, zorganizowała kilka wizyt uczniów szkół technicznych i zawodowych w zakładach pracy, w 2018 roku z inwestorami strefowymi utworzyła Technikum Automatyki i Robotyki, szkołę oferującą modułowy i dualny system kształcenia. Szkołą zarządza Strefa Edukacji sp. o.o., utworzona przez firmy Delia Cosmetics, Ceramika Tubądzin, Miele Technika (Ministerstwo Rozwoju, 2016, s. 46-48; Ministerstwo Przedsiębiorczości i Technologii, 2019, s. 55-57).

ARP S.A. Oddział w Mielcu zorganizował szereg spotkań uczniów z przedstawicielami firm produkcyjnych. Pracownicy spółki podpisali porozumienie z Kuratorium Oświaty w Rzeszowie w celu tworzenia powiązań między edukacją a przemysłem, we współpracy z Centrum Kształcenia Praktycznego i Doskonalenia Nauczycieli w Mielcu zorganizowali wiele spotkań doradców zawodowych z przedsiębiorcami, aby opracować plan praktyk dla uczniów szkół zawodowych. Pracownicy spółki zorganizowali kilka wizyt uczniów w firmach działających w strefie mieleckiej.

Pomorska Specjalna Strefa Ekonomiczna S.A. organizowała wizyty studyjne uczniów szkół technicznych w firmach działających w podstrefach: Bydgoszcz, Łysomice, Włocławek, pod patronatem jej i spółki Wika Polska w ZST we Włocławku utworzone zostały klasy patronackie kształcące w zawodzie technik technologii drewna. Spółka w porozumieniu z władzami Torunia powołała Toruńską Sieć Doradców Zawodowych.

Spółka zarządzająca strefą wałbrzyską wspierała przedsiębiorców w pozyskiwaniu pracowników, organizowała spotkania przedsiębiorców z uczniami, wizyty 
studyjne uczniów szkół średnich w spółkach: Mercedes-Benz Manufacturing Poland, Toyota Motor Manufacturing Poland.

W 2015 roku Katowicka Specjalna Strefa Ekonomiczna S.A. przyznała stypendia dla 34 uczniów szkół z Jastrzębia-Zdroju. Spółka zarządzająca strefą suwalską w tym roku ufundowała 14 stypendiów dla uczniów szkół ponadgimnazjalnych w Ełku, Gołdapi, Suwałkach, cztery stypendia dla studentów PWSZ w Suwałkach. Spółka zarządzająca legnicką strefą ekonomiczną w 2015 roku przygotowała nagrody dla 100 najlepszych uczniów z 14 szkół Legnicy i regionu legnickiego. Nagrody dla najlepszych uczniów w tym roku ufundowała spółka zarządzająca łódzką strefą ekonomiczną. Spółka zarządzająca kamiennogórską strefą ekonomiczną dofinansowała wyposażenie pracowni w Zespole Szkół Technicznych w Jeleniej Górze i w Zespole Szkół Ponadgimnazjalnych w Lubaniu (Ministerstwo Rozwoju, 2016, s. 52; Ministerstwo Przedsiębiorczości i Technologii, 2019, s. 59).

Pomorska Specjalna Strefa Ekonomiczna sp. z o.o. ufundowała pracownie mechatroniki i automatyki w Zespole Szkół Mechanicznych, Elektrycznych i Elektronicznych w Toruniu, wspólnie ze spółką Mondi Świecie dofinansowała wyposażenie pracowni praktycznej nauki zawodu w Zespole Szkół Ogólnokształcących i Policealnych w Świeciu.

Spółki zarządzające strefami ekonomicznymi współpracują z uczelniami i ośrodkami naukowymi. Katowicka Specjalna Strefa Ekonomiczna S.A. wraz z Politechniką Śląską w Gliwicach i przedsiębiorcami ze strefy przygotowała program studiów dualnych, złożyła kilka wniosków o dofinansowanie projektów wspierających rozwój szkolnictwa, w 2017 roku nawiązała współpracę z Wyższą Szkołą Biznesu w Dąbrowie Górniczej, zorganizowała kilka spotkań informacyjnych dla absolwentów szkół średnich. Spółka współpracuje z Wyższą Szkołą Biznesu w Dąbrowie Górniczej i z Akademią Techniczno-Humanistyczną w Bielsku Białej.

Krakowski Park Technologiczny sp. z o.o. nawiązał współpracę z kilkoma uczelniami Krakowa, z AGH, PK, UJ, ARP S.A. Oddział w Mielcu nawiązał współpracę z AGH, Politechniką Rzeszowską, Politechniką Lubelską, Politechniką Świętokrzyską, KUL, UMCS, z Krajowym Klastrem Kluczowym Dolina Lotnicza, jej pracownicy organizowali seminaria dla przedsiębiorców, uczestniczyli w konferencjach organizowanych przez szkoły wyższe i ministerstwa.

Upowszechnianiu społecznej odpowiedzialności, szkolnictwa technicznego służyły również organizowane przez spółki zarządzające strefami ekonomicznymi konferencje, konkursy, festiwale. Konferencje służyły wymianie doświadczeń, wiedzy, były okazją do nawiązania współpracy, konkursy wyzwalały aktywność, przedsiębiorczość, kreowały nowe rozwiązania techniczne, festiwale informatyczne, techniczne służyły kształtowaniu zainteresowań naukowo-technicznych, rozwijaniu wyobraźni, aktywności, kreatywności.

Kostrzyńsko-Słubicka Specjalna Strefa Ekonomiczna S.A. wraz z Zachodniopomorskim Kuratorium Oświaty zorganizowała w Goleniowie w 2015 roku konferencję poświęconą szkolnictwu zawodowemu i współpracy szkół zawodowych z zakładami pracy. Podobną konferencję spółka zorganizowała z Wielkopolskim Kuratorium Oświaty w Poznaniu. Wzięli w niej udział uczniowie wielkopolskich szkół gimnazjalnych, przedstawiciele Volkswagen Poznań sp. z o.o., Politechniki Poznańskiej, Powiatowego Urzędu Pracy w Poznaniu. 
W tym roku spółka zorganizowała wraz z Lubuskim Kuratorium Oświaty w Gorzowie Wielkopolskim konferencję poświęconą rozwojowi szkolnictwa zawodowego w województwie lubuskim. Uczestniczyli w niej uczniowie i przedstawiciele kilkunastu firm. Spółka zorganizowała także kilka spotkań przedstawicieli firm działających w strefie z uczniami szkół zawodowych.

Pracownicy Kostrzyńsko-Słubickiej Specjalnej Strefy Ekonomicznej S.A. brali udział $w$ wielu innych konferencjach, $w$ tym $w$ konferencji zorganizowanej w Gorzowie Wielkopolskim, w konferencji pt. „Szkoła branżowa - przyszłość nowoczesnego biznesu" zorganizowanej przez Ministerstwo Przedsiębiorczości i Technologii w Warszawie, w konferencji zorganizowanej w Szczecinie pt. „Współpraca szkół ze środowiskiem gospodarczym", w konferencji zorganizowanej w Kostrzynie nad Odrą z udziałem przedstawicieli uczelni krajowych i zagranicznych, instytucji międzynarodowych, podczas której zaprezentowano nowe modele współpracy biznesu z nauką i szkolnictwem zawodowym (Ministerstwo Rozwoju, 2017, s. 49-56, Ministerstwo Przedsiębiorczości i Technologii, 2019, s. 50-59).

W 2017 roku pracownicy Katowickiej Specjalnej Strefy Ekonomicznej S.A. i Akademii Techniczno-Humanistycznej w Bielsku-Białej zorganizowali konferencję poświęconą innowacyjności i wdrażaniu nowych technologii, utworzyli Regionalne Forum Doradztwa Zawodowego, uczestniczyli w tworzeniu Klubu Innowatora. W 2018 roku pracownicy spółki zorganizowali konferencję pt. „Dzień Innowatora - Klub Innowatora Katowickiej Specjalnej Strefy Ekonomicznej”, przygotowali kilka spotkań uczniów z właścicielami firm.

Pracownicy Legnickiej Specjalnej Strefy Ekonomicznej S.A. podpisali porozumienie z Państwową Wyższą Szkołą Zawodową im. Witelona w Legnicy i z Instytutem Mechanizacji Budownictwa i Górnictwa Skalnego w Warszawie o współpracy na rzecz rozwoju szkolnictwa zawodowego na poziomie ponadgimnazjalnym i wyższym, uczestniczyli w konferencji pt. „Najlepsze kadry dla nowoczesnej gospodarki”, w konferencji pt. „Współpraca wyższych szkół zawodowych z biznesem”. Pracownicy Łódzkiej Specjalnej Strefy Ekonomicznej S.A. zorganizowali we współpracy z firmami działającymi w strefie konferencję poświęconą kształceniu zawodowemu, uczestniczyli w Forum Pracodawców, w konferencji pt. „Sposób na bezrobocie wśród młodych - dualny system szkolnictwa wyższego w Europie", którą zorganizowała Ambasada Niemiec w Polsce i Fundacja Konrada Adenauera w Polsce.

Pracownicy Pomorskiej Specjalnej Strefy Ekonomicznej sp. z o.o. w 2015 roku zorganizowali konferencję pt. „Stawiamy na szkolnictwo zawodowe”, w następnym roku konferencję pt. „Pomorskie perspektywy zawodowe”, współorganizowali VIII Toruńskie Dni Kariery. W 2018 roku pracownicy spółki zorganizowali wraz z Krajową Izbą Gospodarki Morskiej w Gdyni seminarium pt. „Uczeń, pracownik w gospodarce morskiej".

Pracownicy Wałbrzyskiej Specjalnej Strefy Ekonomicznej Invest-Park sp. z o.o. w 2015 roku zorganizowali dwie konferencje pt. „Mądrzej, czyli jak kształcić dla gospodarki", w których udział wzięli przedsiębiorcy, uczniowie szkół średnich, przedstawiciele samorządów. Wspólnie z Dolnośląskim Kuratorium Oświaty zorganizowali konferencję pt. „Szkoła zawodowa szkołą pierwszego wyboru”, uczestniczyli w VIII Ogólnopolskim Tygodniu Kariery, podczas którego przedstawiono perspektywy rozwoju klas patronackich. W 2018 roku pracownicy spółki z Opolskim Kuratorium Oświaty zorganizowali konferencję poświęconą organizacji szkół branżowych i tworzeniu dla nich 
podstaw programowych (Ministerstwo Rozwoju, 2016, s. 49-55; Ministerstwo Przedsiębiorczości i Technologii, 2019, s. 50-56).

Kształtowaniu aktywności i przedsiębiorczości uczniów szkół zawodowych i technicznych służyły również organizowane konkursy i festiwale. W 2015 roku Katowicka Specjalna Strefa Ekonomiczna S.A. zorganizowała konkurs pt. „Moja szkoła zawodowa”, w którym udział wzięli uczniowie z 20 gimnazjów województwa śląskiego. Krakowski Park Technologiczny sp. z o.o. został patronem strategicznym Międzyszkolnego Festiwalu Informatycznego pt. „Projekt na szóstkę”. Pomorska Specjalna Strefa Ekonomiczna sp. z o.o., zorganizowała konkurs pt. „Wykształcenie pod zatrudnienie”, który był adresowany do uczniów szkół zawodowych i technicznych.

W 2016 roku spółka zarządzająca strefą krakowską objęła patronatem Międzyszkolny Festiwal Informatyczny pt. „Projekt na szóstkę”. Celem festiwalu było nie tylko inspirowanie młodych i zdolnych informatyków do poszukiwania nowych rozwiązań technicznych, ale także tworzenie środowiska zrzeszającego uczniów, studentów, przedstawicieli firm z branży IT. ARP S.A. Oddział w Mielcu współorganizowała Festiwale Nauki i Techniki w Mielcu. Miejscem rozwijającym kreatywność, różne zainteresowania uczniów w Mielcu jest Młodzieżowa Akademia Umiejętności „Leonardo” - jej podopieczni w 2016 roku zdobyli tytuł mistrza i wicemistrza juniorów na Mistrzostwach Świata Modeli Kosmicznych we Lwowie i kilka medali na Mistrzostwach Polski Modeli Kosmicznych.

Pracownicy spółki zarządzającej strefą łódzką wraz z Łódzkim Centrum Doskonalenia Nauczycieli i Kształcenia Praktycznego zorganizowali festiwal zawodów. Spółka zarządzająca strefą tarnobrzeską z Centrum Edukacji Zawodowej w Stalowej Woli zorganizowała konkurs pt. „Skutecznie szukam pracy”, który promował nowe metody i narzędzia poszukiwania pracy przez absolwentów szkół średnich. Pracownicy spółki zarządzającej strefą warmińsko-mazurską w 2018 roku wraz z Kuratorium Oświaty w Olsztynie i Alnea sp. z o.o. zorganizowali pilotażowy program pt. „Laboratorium wspomagania uczniów w wyborze zawodu". W 2018 roku udział w programie wzięło 47 szkół, w kolejnej edycji realizowanej w roku szkolnym 2018/2019 do udziału zgłosiło się 157 szkół i 59 pracodawców (Ministerstwo Przedsiębiorczości i Technologii, 2019, s. 55-58).

Spółki zarządzające strefami ekonomicznymi wiele uwagi przywiązywały do tworzenia klastrów, skoncentrowanych przestrzennie firm z jednego lub pokrewnych sektorów. Ważną cechą klastrów jest to, że firmy skupione w nich współpracują, a jednocześnie konkurują w tych obszarach, gdzie możliwe jest wyzwolenie efektów synergicznych. Konkurencja nie wyklucza współpracy firm i może być motorem ich rozwoju. Obecność w klastrze przynosi firmom liczne korzyści, a uzyskanie informacji o nowych rynkach, technologiach i metodach zarządzania obniża koszty ich działalności przez wykorzystanie zasobów i infrastruktury klastra, daje możliwość wsparcia finansowego $\mathrm{z}$ regionalnych programów operacyjnych.

Z inicjatywy Katowickiej Specjalnej Strefy Ekonomicznej S.A. w 2009 roku utworzony został Klaster Silesia Automotive, od 2015 roku Silesia Automotive \& Advanced Manufacturing. Klaster początkowo skupiał firmy z branży motoryzacyjnej, od 2015 roku także firmy stosujące zaawansowane systemy produkcyjne. Misją klastra zarządzanego od 2015 roku przez Katowicką Specjalną Strefę Ekonomiczną S.A. pozostaje uczynienie z województw śląskiego i opolskiego platformy współpracy pomiędzy przedsiębiorstwami, instytucjami, placówkami naukowymi. 
Klaster Silesia Automotive \& Advanced Manufacturing prowadził monitoring rynku pracy pod kątem analizy zastosowania nowoczesnych materiałów i tworzyw sztucznych w motoryzacji. W 2017 roku skupiał 74 firmy i dziewięć jednostek naukowych. W tym roku klaster zorganizował 12 warsztatów związanych z przemysłem 4.0, automatyzacją i robotyzacją produkcji. We współpracy z Politechniką Śląską w Gliwicach zainicjował utworzenie Śląskiego Centrum Kompetencji Przemysłu 4.0, nawiązał współpracę z sieciami europejskich klastrów: European Automotive Cluster Network i European Connected Mobility Aliance, w 2018 roku podjął realizację projektu EACN for Joint Industrial Modernisation Investmenst - Europejska sieć klastrów motoryzacyjnych na rzecz inwestycji dotyczących modernizacji przemysłowej.

Krakowski Park Technologiczny sp. z o.o. koordynuje prace Krakowskiego Klastra Filmowego utworzonego w 2015 roku. Jego zadaniem jest promocja Krakowa i Małopolski jako miejsc atrakcyjnych dla producentów krajowych i zagranicznych, wspieranie firm w zakresie projektowania i rozwoju nowych technologii, firm zajmujących się promocją filmów. W 2015 roku klaster współorganizował Krakowski Festiwal Filmowy, Festiwal Filmowy w Gdyni, w następnym roku pośredniczył w kilku produkcjach filmowych i telewizyjnych (Ministerstwo Rozwoju, 2016, s. 41-43; 2017, s. 48-55).

Legnicka Specjalna Strefa Ekonomiczna S.A. założyła Dolnośląski Klaster Edukacyjny, uczestniczyła w powołaniu Dolnośląskiego Klastra Motoryzacyjnego, Dolnośląskiego Klastra Lotniczego. Dolnośląski Klaster Edukacyjny prowadzi prace na rzecz utworzenia systemu komunikacji między firmami ze strefy legnickiej a uczelniami i szkołami technicznymi, organizował praktyki zawodowe dla uczniów oraz kampanie informacyjno-promocyjne w zakresie podnoszenia kwalifikacji zawodowych.

Dolnośląski Klaster Lotniczy w 2015 roku utworzyło 17 firm, instytucji i organizacji związanych z przemysłem lotniczym i z otoczenia biznesu. Od chwili powstania jego liderami pozostają Legnicka Specjalna Strefa Ekonomiczna S.A. i HS Wrocław sp. z o.o. Inicjatywę utworzenia klastra wsparło Ministerstwo Rozwoju, Urząd Marszałkowski Województwa Dolnośląskiego, Urząd Miasta Wrocławia, Agencja Rozwoju Aglomeracji Wrocławskiej. Spółka zarządzająca strefą legnicką wspierała udział klastra w wystawach przemysłu obronnego oraz w organizacji wizyt uczniów w firmach położonych w województwie dolnośląskim.

Łódzka Specjalna Strefa Ekonomiczna S.A. wspólnie z Politechniką Łódzką utworzyła Klaster ICT, do którego należy kilkadziesiąt firm IT i ICT z Łodzi i regionu łódzkiego. Celem klastra jest integracja producentów branży informatycznej, elektronicznej, rozwój rynku pracy w obszarze ICT, kształcenie kadr dla branż IT i ICT. Klaster uczestniczył w Łódzkich Dniach Informatyki 2017, które dotyczyły technologii 5G.

Pracownicy Łódzkiej Specjalnej Strefy Ekonomicznej S.A. byli współzałożycielami Łódzkiego Klastra Edukacyjnego i Klastra Lodzistics Logistyczna Sieć Biznesowa Polski Centralnej. Ostatni klaster zrzesza firmy z branży logistycznej, jednostki naukowo-badawcze, instytucje otoczenia biznesu, inne podmioty z sektora logistyki. W 2018 roku klaster uczestniczył w zawarciu porozumienia pomiędzy klastrami logistycznymi z Belgii, Łotwy, Rumunii, Wielkiej Brytanii. W ramach sieci Food Net w przyszłości powstanie Mega Klaster Food in Eco Network, który będzie integrował firmy branży logistycznej i kształtował ich ekspansję na rynki amerykańskie, azjatyckie, bliskowschodnie (Ministerstwo Rozwoju, 2016, s. 49; Ministerstwo Przedsiębiorczości i Technologii, 2019, s. 50-59). 
Przykładów dużego zaangażowania spółek zarządzających strefami ekonomicznymi w promocję przedsiębiorczości, wspieranie szkolnictwa zawodowego, technicznego, w organizację konkursów, festiwali było bardzo wiele. Zaangażowanie to poza kształtowaniem współpracy, współdziałania, tworzeniem platform pomiędzy przedsiębiorstwami, instytucjami, placówkami oświatowymi, służyło także budowaniu ich marki, wizerunku, uznania, sprzyjało formowaniu społeczeństwa aktywnego, mobilnego, twórczego.

\section{PODSUMOWANIE}

Analiza danych zawartych w dokumentach opracowanych przez Ministerstwo Rozwoju, Ministerstwo Przedsiębiorczości i Technologii, Agencję Rozwoju Przemysłu S.A., GUS pozwala sformułować kilka wniosków. Społeczna odpowiedzialność spółek zarządzających polskimi specjalnymi strefami ekonomicznymi w ostatnich kilku latach była dynamiczna i zależała od ich kapitałów, zysków, aktywności zarządów, pracowników. Szczególną rolę odgrywały spółki zarządzające strefami: katowicką, kostrzyńsko-słubicką, łódzką, mielecką, wałbrzyską. Wkład spółek zarządzających tymi strefami w akcje promocyjne szkolnictwa zawodowego, technicznego, w tworzenie klas patronackich, sieci doradców zawodowych, stypendiów dla uczniów szkół średnich, studentów, pracowni praktycznej nauki zawodu, organizację konferencji, festiwali, klastrów był imponujący i przynosił wymierne efekty. Dzięki finansowemu wsparciu spółek zarządzających strefami uczniowie wielu szkół mogli rozwijać swoje umiejętności, kreatywność, aktywność, wzrosło wyposażenie i majątek kilkudziesięciu szkół. Konferencje organizowane przez wymienione i inne spółki zarządzające strefami ekonomicznymi służyły: wymianie doświadczeń, wiedzy, kształtowaniu współpracy, współdziałania, tworzeniu przez spółki klastrów i w niektórych przypadkach zarządzaniu nimi, obniżeniu kosztów działalności wielu firm, pozyskiwaniu informacji o nowych technologiach, rynkach zbytu, metodach zarządzania. Aktywność zarządów i pracowników spółek zarządzających strefami wpływała na podnoszenie kwalifikacji zawodowych pracowników firm działających w strefach i poza strefami, służyła także budowaniu marki spółek, ich wizerunku w lokalnych i regionalnych strukturach społeczno-gospodarczych. Wprowadzona w życie w drugiej połowie 2018 roku ustawa o wspieraniu nowych inwestycji, gwarantująca ulgi i przywileje podatkowe każdej firmie realizującej nowe inwestycje, szczególnie w rejonach o podwyższonym poziomie bezrobocia i w miastach tracących funkcje społeczne i gospodarcze oraz wzrastająca dekoniunktura gospodarcza niewątpliwie ograniczą dochody spółek zarządzających strefami ekonomicznymi, a tym samym ich aktywność na polu społecznej odpowiedzialności.

\section{Literatura \\ References}

Ernst \& Young (2011) (2020, 12 stycznia). Specjalne strefy ekonomiczne po 2020 roku. Analiza dotychczasowej działalności oraz perspektywy funkcjonowania. Pozyskano z https://www. ey.com/Publication/vuLUAssets/Specjalne_strefy-ekonomiczne_po_2020_roku_raport/\$FILE/ey_sse_po_2020_roku_28092011.pdf

GUS (2019). Mały rocznik statystyczny Polski. Warszawa: Zakład Wydawnictw Statystycznych.

GUS (2000). Rocznik statystyczny Rzeczypospolitej Polskiej. Warszawa: Zakład Wydawnictw Statystycznych. 
Jastrzębska, E. (2013). Społeczna odpowiedzialność liderów CSR w Polsce - wyniki badań. Prace Naukowe Uniwersytetu Ekonomicznego we Wrocławiu, 288, 37-48.

Kozaczka, M. (2015), Specjalne strefy ekonomiczne w Polsce 2008-2014. Lublin: Katolicki Uniwersytet Lubelski Jana Pawła II.

Ministerstwo Przedsiębiorczości i Technologii (2018). Informacja o realizacji ustawy o specjalnych strefach ekonomicznych. Stan na 31 grudnia $2017 \mathrm{r}$.

Ministerstwo Przedsiębiorczości i Technologii (2019). Informacja o realizacji ustawy o specjalnych strefach ekonomicznych. Stan na 31 grudnia $2018 \mathrm{r}$.

Ministerstwo Rozwoju (2016). Informacja o realizacji ustawy o specjalnych strefach ekonomicznych. Stan na 31 grudnia $2015 \mathrm{r}$.

Ministerstwo Rozwoju (2017). Informacja o realizacji ustawy o specjalnych strefach ekonomicznych. Stan na 31 grudnia $2016 \mathrm{r}$.

Raport roczny Agencji Rozwoju Przemysłu S.A. za 2016 r. (2017). Warszawa: Agencja Rozwoju Przemysłu.

Rozporządzenie Ministra Przedsiębiorczości i Technologii z dnia 29 sierpnia 2018 r. w sprawie ustalenia obszarów i przypisania ich zarządzającym (Dz.U. z 2018 r., poz. 1698).

Rozporządzenie Rady Ministrów z dnia 28 sierpnia 2018 r. w sprawie pomocy publicznej udzielanej niektórym przedsiębiorcom na realizację nowych inwestycji (Dz.U. z 2018 r., poz. 1713.

Ustawa z dnia 22 stycznia 2015 r. o zmianie ustawy o funkcjonowaniu górnictwa węgla kamiennego w latach 2008-2015 oraz niektórych innych ustaw (Dz.U. z 2015 r., poz. 143).

Ustawa z dnia 30 kwietnia 2004 r. o postępowaniu w sprawach dotyczących pomocy publicznej (Dz.U. z 2004 r., nr 123, poz. 1291).

Ustawa z dnia 10 maja 2018 r. o wspieraniu nowych inwestycji (Dz.U. z 2018 r., poz. 1162).

Ustawa z dnia 30 maja 2008 r. o zmianie ustawy o specjalnych strefach ekonomicznych (Dz.U. z 2008 r., nr 118, poz. 746).

Ustawa z dnia 23 czerwca 2006 r. o zmianie ustawy o specjalnych strefach ekonomicznych oraz niektórych ustaw (Dz.U. z 2006 r., nr 141, poz. 997).

Ustawa z dnia 20 października 1994 r. o specjalnych strefach ekonomicznych (Dz.U. z 1994 r., nr 123, poz. 600).

Ustawa z dnia 14 grudnia 2016 r. Prawo oświatowe (Dz.U. z 2017 r., poz. 59).

Ustawa z dnia 14 grudnia 2016 r. Przepisy wprowadzające ustawę Prawo oświatowe (Dz.U. z 2017 r., poz. 60).

Marian Kozaczka, prof. dr hab. Uniwersytet Pedagogiczny w Krakowie, Wydział Nauk Społecznych, Instytut Prawa, Administracji i Ekonomii, Katedra Polityk Publicznych. Zainteresowania badawcze: polityka społeczna, polityka gospodarcza, finanse, ekonomia innowacji.

Marian Kozaczka, professor, Pedagogical University of Krakow, Faculty of Social Sciences, Institute of Law, Administration and Economics, Department of Public Policies. Research interests: social policy, economic policy, finance, innovation economy.

ORCID: 0000-0002-6980-415X

\title{
Adres/address:
}

\author{
Uniwersytet Pedagogiczny w Krakowie \\ Wydział Nauk Społecznych \\ Instytut Prawa, Administracji i Ekonomii \\ Katedra Polityk Publicznych \\ ul. Podchorążych 2, 30-084 Krakow, Polska \\ e-mail: marian.kozaczka@up.krakow.pl
}

